О. П. Білих

\title{
ІМЕННІ ПРИКМЕТНИКИ В ЦЕРКОВНОСЛОВ'ЯНСЬКІЙ МОВІ УКРАЇНСЬКОЇ РЕДАКЦІї КІНЦЯ XVI - XVII СТ.: ОСОБЛИВОСТІ ФУНКЦІОНУВАННЯ ТА ВІДМІНЮВАННЯ
}

Білих О. П. Іменні прикметники в церковнослов'янській мові української редакції кінця XVI XVII ст.: особливості функціонування та відмінювання.

У статті проаналізовано особливості функціонування та відмінювання іменних прикметників церковнослов'янської мови української редакції кінця XVI - XVII ст. Зроблено висновок про вплив української мови на ці одиниці.

Ключові слова: церковнослов'янська мова української редакції, іменні прикметники, відмінкові форми прикметників.

Билых А. П. Именные прилагательные в церковнославянском языке украинской редакции конца XVI - XVII ст.: особенности функционирования и склонения.

В статье проанализированы особенности функционирования и склонения именных прилагательных церковнославянского языка украинской редакции конца XVI - XVII ст. Сделан вывод о влиянии украинского языка на эти единицы.

Ключевые слова: церковнославянский язык украинской редакции, именные прилагательные, падежные формы прилагательных.

Bilykh O. P. Nominal adjectives in the Ukrainian edition of Church Slavonic language of the end of the XVI - XVII centuries: the pecularities of functioning and declination.

The article under consideration analyzes the pecularities of functioning and declination of nominal adjectives of Church Slavonic language of the end of the XVI - XVII centuries. A conclusion about influence of Ukrainian language on these points was made. adjectives.

Key words: the Ukrainian edition of Church Slavonic language, nominal adjectives, case forms of

Однією з особливостей слов'янських мов у давні періоди їхнього розвитку була наявність двох різновидів прикметникових форм: іменних (нечленних) та займенникових (членних). 3 часом система цих форм зазнавала змін, у результаті яких, крім іншого, відбувалося звуження функцій іменних прикметників. Хоча цей процес був загальнослов'янським, доля іменних форм склалася по-різному навіть у таких близькоспоріднених мовах, як східнослов'янські. У російській мові вони $€$ достатньо вживаними одиницями (в наз. в. одн. й мн. в предикативній функції), меншою мірою представлені в білоруській, ще менше їх у мові українській. Найголовніші етапи розвитку цих форм в українській та інших східнослов'янських мовах уже встановлені й описані в спеціальній літературі [12, с. 119-134, 296-300; 2, с. 32-36, 56-63; 11, с. 188-199; 4, с. 101-105 і ін.]. При цьому видається цікавим i, на нашу 
думку, актуальним з'ясувати особливості функціонування й відмінювання іменних прикметників у церковнослов'янській мові. Адже відомо, що ця мова довгий час використовувалася східнослов'янськими народами i взаємодіяла з їхніми мовами. Особливо активною така взаємодія була в Україні в кінці XVI - XVII ст. [7, с. 147]. Крім того, саме в Україні цього часу була здійснена кодифікація церковнослов'янської мови [5; 6]. Завдяки цьому, а також у результаті розвитку книгодрукування Україна в кінці XVI i майже протягом усього XVII ст. була центром, де вироблялися церковнослов'янські норми, що впливали на весь православний слов'янський світ $[10$, с. 61$]$. Тому всебічне дослідження церковнослов'янської мови української редакції кінця XVI - XVII ст. потрібне для глибшого пізнання історії не лише української, а й інших слов'янських літературних мов.

У зв'язку зі сказаним метою пропонованої розвідки є з'ясування особливостей функціонування та відмінювання іменних прикметників у церковнослов'янській мові української редакції др. пол. XVI - XVII ст. Матеріал для дослідження дібрано шляхом суцільної вибірки переважно зі стародруків (список джерел див. наприкінці статті). У великих за обсягом пам'ятках обстежений не весь текст, а вибірки розміром у 500 повнозначних слів. Із ОБ обстежено 100 таких вибірок, із $B B-50$.

У старослов'янській мові іменні та займенникові прикметники розрізнялися певними особливостями синтаксичного функціонування, зокрема тим, що роль частини складеного іменного присудка могли виконувати загалом лише іменні прикметники [9, с. 96], означеннями ж виступали обидва різновиди. Крім того, лише іменні форми мали присвійні прикметники [1, с. 157; 9, с. 91], інші могли бути як нечленними, так i членними.

У церковнослов'янській мові кінця XVI - XVII ст. прикметники характеризувалися в основному тими ж особливостями. Так, у предикативній функції виступали насамперед іменні форми: гласъ твой сладоКъ и оБразЪ Твой красен' ОБ (3) 45 (2)*; Аа непорочно БУАЕТЪ слоуженїе ВВ (3) 10 зВ.; м弓Аа ваша мншга Ч 1617, 99; скорвнн въша słı ЄвЛ 1644, 59. Те, що роль іменної частини присудка була притаманна в першу чергу нечленним прикметникам особливо помітно із прикладів, де різні форми прикметників ужиті в одній фразі, але в різних функціях: како мудръ сей преподобный мужъ ПМ 66; Мюто вы(ст) stм0 ... наважденїе в ьсовское ПКП 220 зв.; Иноческое жнтїє естЪ подвнжно,

\footnotetext{
* Після скороченої назви джерела подано номер аркуша або сторінки, звідки взятий приклад. Позначка зв. вказує на зворот аркуша. Цифра в дужках перед позначенням аркуша в $О Б$ та $B B$ вказує на номер рахунку. Аркуші першого й другого рахунку спеціально не позначаються. Цифра (2) після номера аркуша в ОБ вказує на праву колонку, ліва спеціально не позначається. Виносні літери подані в круглих дужках у рядку, таким же способом подаються ъ $\mathbf{~ i ~} \mathbf{b}$, позначені в текстах надрядковими знаками. Цитати із перевидань подаються звичайним шрифтом курсивом.
} 
мїрскоє же жнтїє с૪етрУАно ПКП 21 зв. Хоча слід відзначити, що зрідка в обстеженому матеріалі предикативну функцію виконують також членні прикметники: ложное ихъ бысть об рускаа ПМ 51; въистинну страшный и грозный день онь будеть ... грњшнымъ, свњтоносный же и радостный ... праведнымь ПМ 158; ТЫ єсн вогатый во ми̃стн ПКП 13 нн. Випадки такого використання членних прикметників у XVI ст. трапляються і в українській [3, с. 103] та інших слов'янських мовах [9, с. 101]. В атрибутивній функції в розглянутому матеріалі вживалися як членні, так і нечленні прикметники.

Присвійні прикметники в обстежених пам'ятках мали переважно

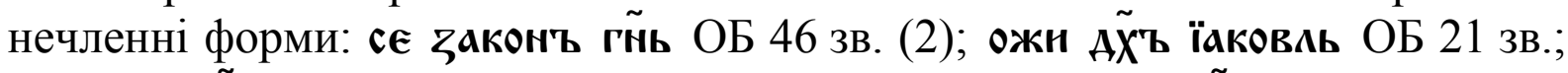

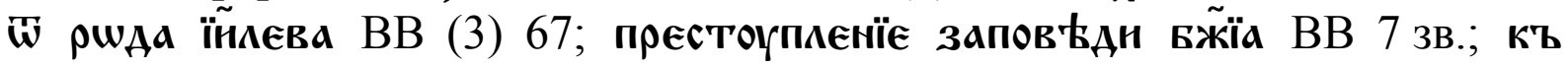
овразУ GпснтелевУ ПКП 116. Те, що при вживанні присвійних прикметників в обстежених текстах перевагу надавали насамперед нечленній формі, яскраво демонструють випадки, коли присвійні й неприсвійні прикметники виступають в одній і тій же функції в межах

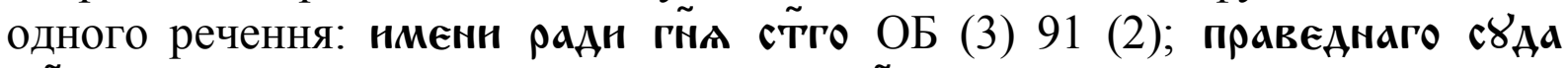
Бӝїа ВВ 45; снма ч(c)тнаго ...кр(с)та Гйа Ч 1617, 140 зв.; преподобный воинъ Христовъ ПМ 125; убоимся неумылтнаго суда Господня ПМ 156; пр(с)том૪ Именн Бӝїю ПКП 138. Водночас, не є особливо рідкісними в розглянутому матеріалі й членні форми присвійних прикметників. Частіше вони вживаються в непрямих відмінках, інколи в наз.: Третяковая же жена ... воду ... съкры ПМ 113; б телесн вратнагш ПКП 19 зв.; къ в в $p$ Б ... Христовой Син 172; Божїей честн СмГр 38; съ ... церемъ їобАннъ(м)

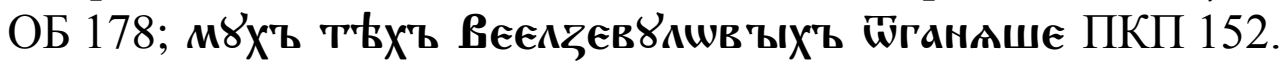

Крім того, однією з особливостей розглянутого матеріалу є те, що в ньому трапляються випадки, коли нечленні й членні прикметники, виконуючи одну й ту ж функцію (частіше атрибутивну), вживаються поряд, в одному реченні: Родила еси ... не человька проста, нъ Бога

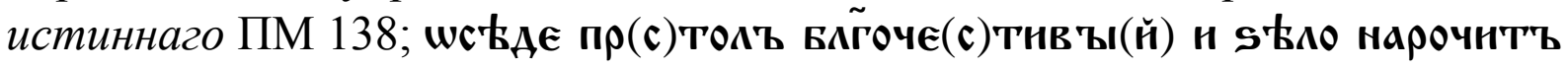
мужъ ЛМГ 26; воспрїАть жнтїє Иноческое жестоко ПКП 230; в(ъ)

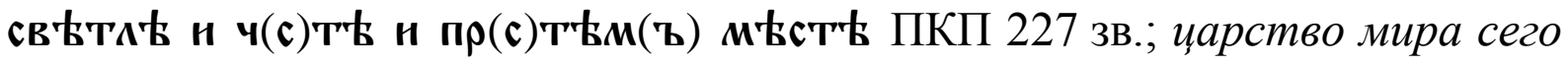
... тльнное есть и временно ПМ 125. Ці й інші випадки, можливо, свідчать про те, що в кінці XVI - XVII ст. членні й нечленні прикметники в межах церковнослов'янських текстів (особливо в атрибутивній функції) не протиставлялися, а сприймалися, очевидно, як певною мірою рівноправні варіанти. Таке ставлення до обох різновидів прикметникових форм підтверджує, на нашу думку, й граматика М. Смотрицького, у якій автор не формулює правил уживання членних і нечленних прикметників, а лише зауважує, що нечленні виникають через усічення $[6$, с.111]. У прикметникових парадигмах граматики подані обидва різновиди форм (якщо вони, на думку автора, існують) із членним прикметником на 


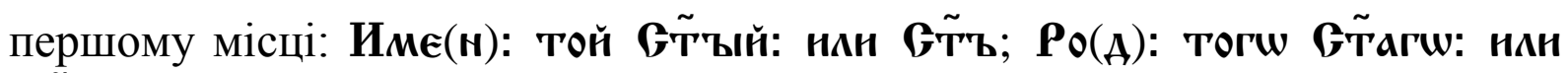
Gт्та СмГр 148 і т. д.

В українській літературній мові XVI - XVII ст. іменні форми прикметників також використовувалися, однак, за спостереженнями дослідників, уже виходили з ужитку. Представлені були у зв'язку 3 особливостями синтаксичного функціонування переважно в наз. в. одн. i мн. Форми ж непрямих відмінків на цей час трапляються в пам'ятках лише спорадично [3, с. 103; 2, с. 59]. У церковнослов'янських текстах кінця XVI - XVII ст. іменні прикметники, хоча й кількісно значно поступалися членним, були загалом достатньо вживаними (крім деяких форм непрямих відмінків у множині) i, порівняно 3 українською мовою, очевидно, сприймалися як характерна ознака церковнослов'янської. Такий висновок дозволяє зробити, зокрема, й матеріал церковнослов'янсько-українських словників того часу. Так, у словнику Л. Зизанія в реєстровій частині виявлено 25 іменних прикметників, 21 із них перекладений прикметником членним: Бйже(н) щаслнвы(й) 26; Благодарстве(н), подачанвый 30; золъ, заый 49; і ін. У словнику П. Беринди із 90-а нечленних прикметників реєстрової частини 50 перекладені лише членними, або в перекладній частині серед відповідників на першому місці знаходиться членний прикметник: Бесмртен: Несмертемный 5; Бкг̃гденственъ: фаслнвый 7; Аревлнъ: Деревлный 58; Довль: Gталый, м४жественъ 51 і ін. Ще у 27-и випадках обидві форми перекладаються членним прикметником: ГовЊннъ, йный: оүчтнвый, че(ст)ный ... 44; Гордъ,

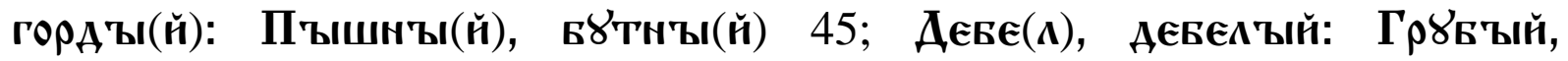
толсты(й) 50 і ін.

Відмінювалися іменні прикметники у церковнослов'янській мові української редакції кінця XVI - XVII ст. загалом так, як i в старослов'янській, тобто прикметники чол. і середн. родів як іменники 3 давніми основами на $*$, *jo, а прикметники жін. р. як іменники з основами на $* a,{ }^{*}$ ja.

У проаналізованому матеріалі зафіксовані всі можливі форми нечленних прикметників (однини й множини). Однак за кількістю вживань ці форми не є рівнозначними. Частіше нечленні прикметники виступають, як і в тогочасній українській мові, в наз. в. одн. і мн., непрямі ж відмінки представлені значно меншою кількістю вживань. Різниця за кількісною представленістю серед проаналізованих іменних прикметників між формами наз. в., з одного боку, та формами непрямих відмінків, - $з$ іншого, особливо помітною є у множині. Причому непрямі відмінки нечленних прикметників, крім знах., виявлені лише в окремих із обстежених пам'яток (в основному в $O Б$ та $Ч$ 1617, менше у $B B$ та $П М$ ). Це свідчить, очевидно, про те, що в церковнослов'янській мові кінця XVI - XVII ст. відбувався процес руйнування парадигми іменних прикметників. Однією 3 його причин був уплив української мови, у якій у XVI - XVII ст. форми 
непрямих відмінків іменних прикметників, насамперед множини, вже фактично вийшли з ужитку [3, с. 107; 2, с. 60].

Далі подаємо характеристику особливостей творення відмінкових форм іменних прикметників за числами та родами.

\section{Однина}

Називний відмінок. У наз. в. одн. іменні прикметники чол. р. мали нульові закінчення, середн. - -о, -є, жін. - -а, -л: Правєденъ есть Г̈ь ОБ (3) 120; вУАн празденъ на празнословїе ВВ (4) 89; се песъ чернъ ста ПКП 74 зВ.; Прниагателное ест' АевАтогУБо СМГр 41; мҺсто тЊсно Естъ ПКП 207; БЫсть слово Гйе ОБ 195 (2); велнКа КААтВа БАШЕ ОБ 121; нЊсть красна пъснь въ оцстеХъ грҺшннка ПКП 21 ; гора сїона ОБ 76 (2). У староукраїнській літературній мові, зокрема й кінця XVI XVII ст., давня іменна форма наз. в. прикметників жін. р. співіснувала 3 новою повною стягненою. Обидві форми мали однакові закінчення, що викликає певні труднощі під час їхньої характеристики [3, с. 104; 2, с. 59]. Що ж до аналізованого матеріалу, то майже всі розглянуті форми є, без сумніву, іменними, лише окремі (зафіксовані у ПМ), очевидно, можна вважати новими стягненими. Це власні назви, запозичені з української мови: Быковска, н اкая вдова ... село ... дръжаше ПМ 102; Княгиня Анна Корецкая Хоткевичувна ПМ 66; въ веси ... Рыљккова Воля 104.

Родовий відмінок. У род. в. одн. іменні прикметники чол. і середн. родів характеризувалися закінченнями -а (після твердих приголосних, також після шиплячих) та -А (після м'яких): $\mathbf{w}$ града камемна ОБ 101 зВ.

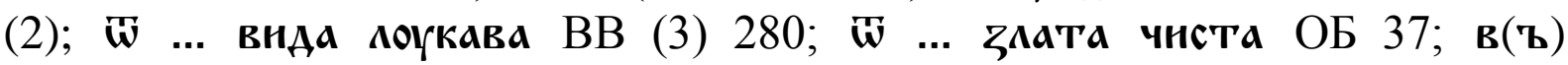

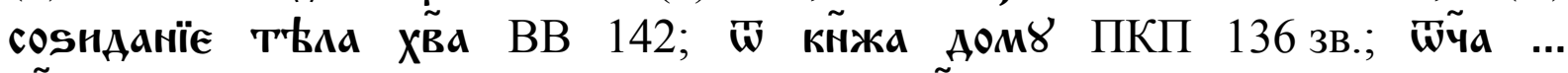

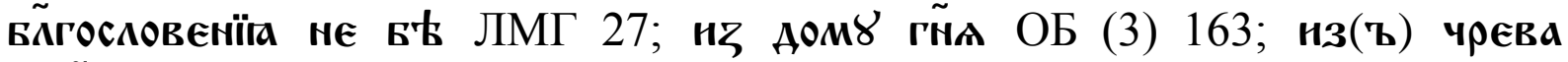
мтерна ВВ 129 зв.

Для прикметників жін. р. були характерними закінчення -ы, -А, а також в окремих випадках -н. Після основ на тверді приголосні використовувалося переважно -ы: кладазь воды жнвы ОБ (3) 45 зв.; мҺры радн Ятїхотворны СмГр 487; Не Бысть Доскн каменны ПКП 118; оть любве Христовы ПМ 125; Вынецъ съ Гиавы Іговы ПКП 107. Якщо основа закінчувалася на задньоязиковий, у всіх зафіксованих випадках виступало закінчення -н: $\mathbf{d}$ мнца снкы $\operatorname{crp}(\mathbf{z})$ скн ОБ (3) 110

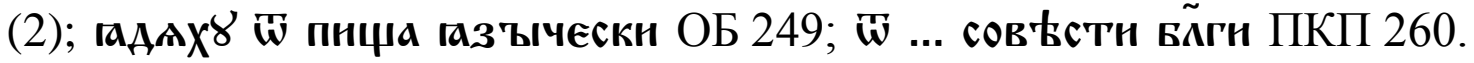

Після м'яких приголосних у переважній більшості випадків представлене закінчення -л: $\mathbf{6}$ горы ефремма ОБ 173; $\mathbf{6}$ кознн дїавока ПКП 151; $\mathbf{\omega}$ рУкн Г(c)дна ПКП 38; оть лести вражіа ПМ 147. Інколи в такого типу прикметниках трапляється -н: въ срьтенїє аны жены їероводммн ОБ 163 (2); оу мемьхолы Ачин саоумн ОБ 143. Зафіксовані також (у $B B)$ однокореневі варіанти з обома закінченнями. Частотнішими при цьому є утворення на -А (-а): с४дъ правды Бӝїа ВВ (3) 221 - кончнна 


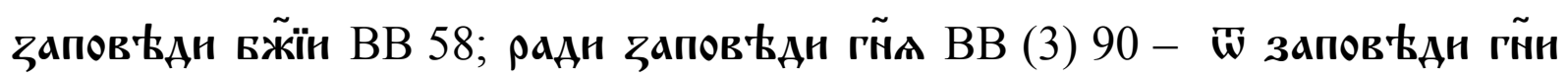
ВВ (3) 269. У граматиці М. Смотрицького для род. одн. нечленних прикметників жін. р. 3 основами на м'які приголосні рекомендовано лише -А: Ро(А): тол ... ннща СмГр 156; тол ... сйовна СмГр 161.

Давальний відмінок. Форми дав. в. нечленних прикметників у розглянутому матеріалі представлені, на відміну від тогочасної української літературної мови [3, с. 106; 2, с. 59], порівняно великою кількістю вживань. Хоча слід відзначити, що в деяких пам'ятках (у ЗизГр, ЛМГ) вони взагалі не виявлені. Прикметники чол. та середн. родів у дав. одн. мали закінчення -४ (після твердих приголосних) та -ю (після м'яких): м૪жескУ полУ ОБ 121; мншгодоврод Стел(ь)нУ м४жу ВВ (4) 87; слогУ естество(м) кратк8 СМГр 489; страстноу жнтїю сеБе нзАавъ ВВ (4) 87; велику ведру сущу ПМ 102; маслУ же АревАнУ не сУџУ ПКП 69 ЗВ.; АОМУ Їаковлю ОБ (3) 96; оле ... Божію милосердію ПМ 112; по век ьнїю Бчю ЛМГ 25.

Прикметники жін. p. у дав. в. одн. характеризувалися закінченнями - $\mathbf{b}$ та -н. Флексія - $\mathbf{b}$ використовувалася після основ на тверді приголосні, -н - після основ на м'які: къ ложннцы олоферновь ОБ 259;

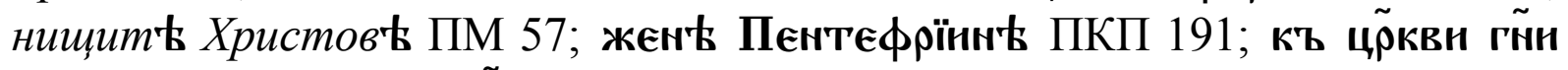
ОБ 249; токовьй Бӝїн вл(А)ти ВВ (3) 114. Парадигма останнього прикметника (вожїй) подана в граматиці М. Смотрицького, при цьому в дав. в. представлена лише членна форма: Да(т): той Божїєй СмГр 164.

Знахідний відмінок. Нечленні прикметники чол. р. в знах. в. одн. мають форми, подібні до наз. або род., залежно від того, назвою неістоти чи істоти є означуваний іменник: на поток(ъ) кеАръскъ ОБ 183; въ столпь сланъ ПМ 175; мамодш̈на же чйка кто оүкротнт(ъ) ОБ (3) 36;

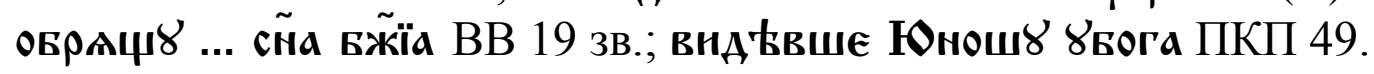

Прикметники середн. р. в усіх випадках у знах. в. мають форму, яка дорівнюе наз.: прннесоша ... АревАно масло ОБ 42 (2); слово нспоустн празно ВВ (3) 79; Аа не тУне прїмметъ знаменїе вратне ПКП 250.

Знах. в. прикметників жін. р. характеризується закінченнями -8 (після твердих приголосних, зокрема й після ч) та -ю (після м'яких): ОБАечетСА ... ВЪ срачнцУ мнАнУ ОБ 46 зВ.; молбу теплу ... сотвори ПМ

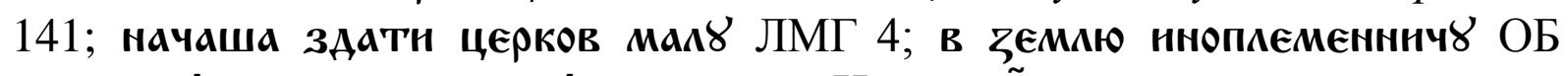
138; обрЊтоша ногу челов

Орудний відмінок. У староукраїнській літературній мові форми ор. в. одн. іменних прикметників представлені лише поодинокими випадками. У пам'ятках XIV - XV ст. вони взагалі, за спостереженнями дослідників [2, c. 60], не засвідчені, у пам'ятках XVI ст. виявлено всього кілька вживань $[3$, с. 106]. Відсутні ці форми також i в граматиках Л. Зизанія та М. Смотрицького. У прикметникових парадигмах тут в ор. в. одн. подані

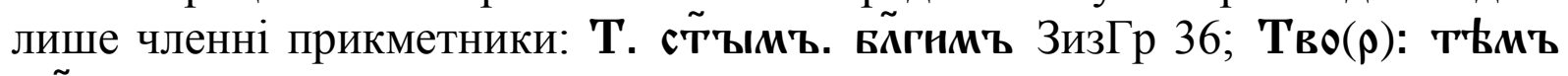

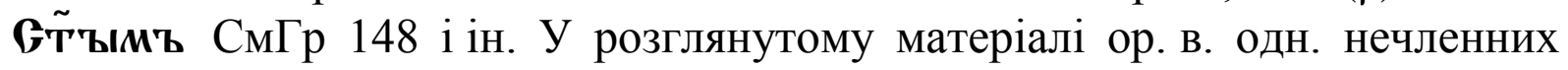


прикметників хоча й представлений, однак $є$ найменш уживаною (в однині) прикметниковою формою. Випадки іï використання виявлені в основному в пам'ятках кінця XVI ст. (в $O Б$ та $B B$ ), в інших вона трапляється дуже рідко.

Нечленні прикметники чол. і середн. родів у цьому відмінку мають закінчення -омъ (після твердих приголосних) та -емъ (після м'яких): съ народом векнкомъ ОБ (4) 1 (2); съ чйкомъ газычномъ ОБ (3) 56; нравомъ ч(с)тномъ ВВ (3) 111 зв.; органом зміиномъ въображся ПМ 152; ОчнСТНТ' АОМЪ ... АРЕВОМ КЕАРОВОМЪ ОБ 51 ЗВ. (2); СЪ ОАОВОМ чНСТОМЪ ОБ (3) 135 (2); предъ Рождествомь Христовомъ ПМ 104; пре(А) пнцемъ гйемъ ОБ 138; страхом велїЕмъ ОБ 259; гАасом велїЕмъ ВВ (3) 25.

У жін. р. форми ор. в. нечленних і членних прикметників збігаються.

Місцевий відмінок. У місц. в. одн. іменні прикметники всіх родів характеризувалися закінченнями -t або -н. Флексія -t виступала в переважній більшості випадків після основ на тверді приголосні: ма одрћ

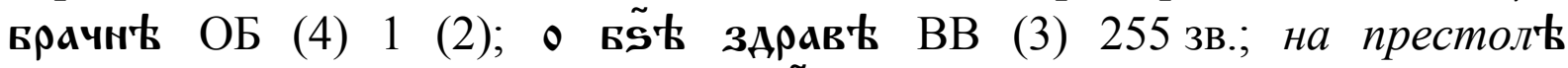
божественнь ПМ 163; на мьсть сти' ОБ 46 зВ.; въ внд ПКП 33 нн; на трапез' чнст' ОБ 56 зв.; в мюввн Хй̈' ВВ (3) 243 зВ. При цьому перед закінченням відбуваються чергування $2 / / 3$ ', $\kappa / / u^{\prime}$ та ск//cm': въ ... оужас' мноз' ПКП 167; в(ъ) недолз' временн ЛМГ 27;

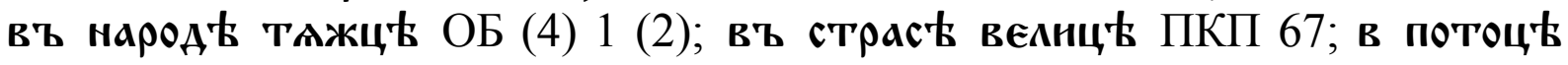
кеАрсть ОБ 183; w чннћ Грамматнчесть СмГр 473; w А кемар(ь)ст' нин поварст' ВВ (3) 24.

Після основ на м'які приголосні (зокрема й на ч) використовувалося закінчення -н: въ закон Б Господни ПМ 176; в секь модвлн ОБ 175 (2); о съкровнщн Бӝїн ВВ (3) 269; на секь нноплеме(н)ннчн ОБ 138 (2).

Зрідка в обстеженому матеріалі трапляються випадки, коли замість -н вживається -ь: в горь єфранмк ОБ 106 зв.; въ овластн Gватославлt ПКП 78. В ОБ зафіксовані однокореневі варіанти з обома закінченнями: въ ъеммн Ханаанн ОБ 106 зв. (2) - в ъемкн Ханаан' ОБ 121. Крім того, серед проаналізованих форм ор. в. одн. виявлено утворення не -є: въ внноградь га(А)дове ОБ (3) 45.

Кличний відмінок. У кл. в. іменні прикметники чол. р. могли мати або нульове закінчення, як у наз., або -є. Кількісно переважають форми із

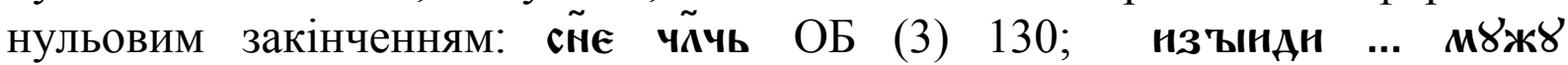
Безаконенъ ОБ 148; w роде невЪренъ ОБ (5) 10; радуйса Храме Гйь Ч 1617, 159 зв.; раве Гйь ПКП 104 зв. Однак не є рідкісними й утворення

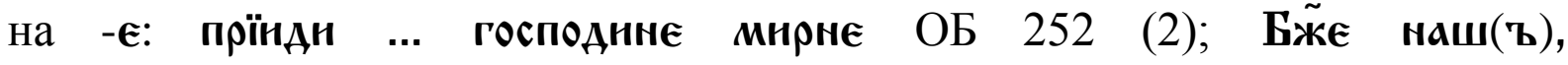

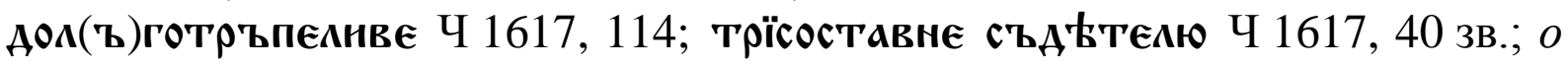
милостиве Владыко ПМ 152. При цьому субстантивовані прикметники у всіх випадках мають кл. в. на -е: Аоколь льностнве въ弓лежншн ОБ (3)

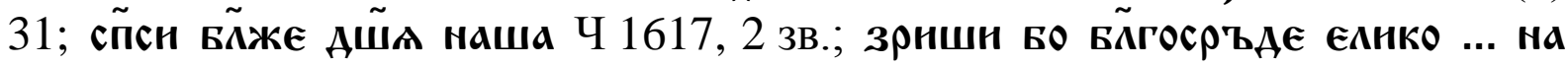




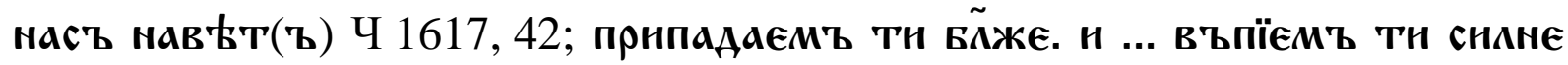
Ч 1617, 56. Обидва різновиди кл. в. прикметників чол. р. були представлені в старослов'янській мові, хоча форми на -є як поодинокі [9, с. 61]. Вказані форми подані також у граматиці М. Смотрицького: Зва(т): w Gт̃ G те СмГр 148.

Прикметники середн. та жін. родів у кл. в. у всіх випадках мають такі ж закінчення, як і в наз.: тек' съгрьшнхом(ъ) пожданїє ійлево ОБ (3) 100 (2); w ... страно грђшна ОБ (3) 71; Рад бйса пажнти Хйва ПКП 100.

\section{Множина}

Особливістю розглянутих множинних форм нечленних прикметників, порівняно з українськими, є те, що вони зберегли окремі закінчення для різних родів. В українській мові XVI - XVII ст. нечленні прикметники мають у множині спільні форми для всіх родів [3, с. 106].

Називний відмінок. У наз. в. мн. іменні прикметники чол. $\mathrm{p}$. характеризувалися закінченнями -н, -ы, а також в окремих випадках -ъ. Більш поширеним у розглянутому матеріалі $\epsilon-\mathbf{н}$, первісне для нечленних прикметників чол. р. в наз. в. (як і для іменників із давніми основами на * $o$, *jo): что есте страшинвн ОБ (5) 3; своводнн сдть сйшве ВВ 82 зВ.; Алъжнн есмы ... молнтнсА Ч $1617,15 \mathrm{нH}$; готови бо есмьл умрети ПМ 63; ч(с)тни выша Арбзи твон ПКП 32 нн. Це закінчення використовувалося для творення аналізованих форм у старослов'янській мові [8, с. 125], лише воно рекомендоване і граматикою М. Смотрицького:

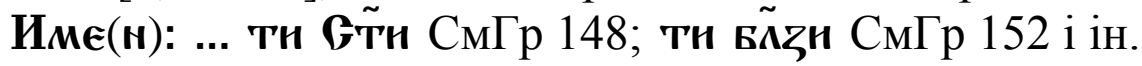

Меншою кількістю вживань представлене -ы, хоча й воно є також достатньо частотним: вњша славы тЊкомъ ОБ 211 ; съсодАЫ среБрены ВВ (3) 90 зВ.; мечн шБондУ шстры Ч 1617, 62 зв.; дворы будуть nусты ПМ 98. Флексія -ы, як відомо, за походженням є показником знах. в. мн. Унаслідок утрати формального протиставлення наз. та знах. відмінків вона поширилася і серед форм наз. в. В українській літературній мові XVI ст. -bl була основним засобом творення форм наз. в. мн. іменних прикметників [3, с. 106]. У зв'язку з цим звертає на себе увагу те, що в авторському тексті граматики М. Смотрицького іноді трапляються форми на -ы, хоча вони не подані в парадигмах: єднносложны ... гілы СмГр 356; стт̈Ховъ родн соу(т) трннадеслтолнчны СмГр 494.

Після твердих приголосних закінчення -ы та -н вимовлялися, очевидно, однаково. Про це свідчить достатньо велика кількість зафіксованих в обстеженому матеріалі однокореневих варіантних форм, зокрема і в межах однієї пам'ятки: могтн єго мЊААнн ОБ 155 - шиємы МҺААнЫ ОБ (4) 6; ПадшШа ннц(ъ) оужаснн ПКП 115 зв. - оужасны выша w שв女тt' ПКП 114. Інколи такі форми трапляються навіть на одній сторінці: црен їоудннн ОБ 183 (2) - церн їољАнны ОБ 183 (2); Аокжнн ... 
БАГ(А)ренїє во(З)сыматн ПКП 10 нН - АОАжнЫ ЕсмЫ БАГ(А)рнТН ПКП 10 Нн; празАнн преБЫсте ПКП 175 - стойте ТУ праЗАнЫ ПКП 175.

Перед закінченням -н в більшості випадків відбуваються чергування 2//3', к//u': назн роднхомса ПКП 78; мншзн въстаютъ Ч 1617, 47; слозн

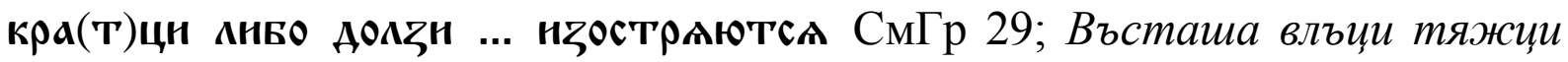
ПМ 147. Зафіксовані також (в $О Б)$ форми, в яких чергування відсутні: гіаша Хама Њн сгрскы ОБ 150 (2); власы его шнрокн ОБ (3) 46.

Зрідка форми наз в. мн. іменних прикметників чол. р. могли мати закінчення -ь (у $B B$ та ПКП): готовь въ огнь ВВ (3) 91 зв.; отроцн Ростнславль ПКП 176 зв.; сладц шьрьтах४сл (хліби) ПКП 203 зв.

Прикметники середн. р. в наз. мн. мали, за винятком кількох випадків, закінчення -а, -А (як і в старослов'янській мові [8, с. 125], а також відповідно до рекомендацій граматики М. Смотрицького: Име(н) ... та ст̃⿱a СмГр 150; та сйовна СмГр 163). Флексія -а виступала після твердих приголосних, -А - після м'яких: многа с8ть ЖвращенїА ОБ (3) 100 (2); сладка ... словеса твОА ВВ (3) 269 зв.; жнва бољАОу(т) ср(А)ца

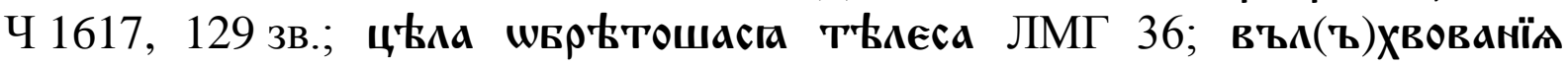
ваша с8А ОБ (3) 130. Крім того, поодинокими вживаннями представлені (у Ч 1617 та ПКП) форми наз. в. мн. прикметників середн. р. на - - П : Трончны Ч 1617, 65; право(с)кавны с8т(ь) (правила) н Аш̈поле(з)ны ПКП 27 нн. Такі утворення в церковнослов'янських текстах почали 3'являтися, очевидно, в результаті впливу української мови, в якій на цей час короткі прикметники всіх родів у наз. в. мн. вже мали однакові закінчення -bl (-u) [3, с. 106].

Іменні прикметники жін. р. в наз. в. мн. характеризувалися майже у всіх випадках закінченнями -ы, -н. Частотнішим серед проаналізованих форм є -Ы: нечнсты мйтвы ОБ (3) 36 (2); р४кн ... полны крове ОБ (3) 71 (2); страстн с४ть с४гУБы СмГр 487; Равны в(ъ) томъ с४ть н Пещеръ ... къ Мг̃сн ПКП 27 зв. Закінчення -н представлене насамперед після задньоязикових приголосних: страны многн ОБ (3) 140 (2); многн АщЕрА ПКП 37 зв.; Ащерн страньскн ОБ (3) 140 (2). Хоча інколи в такій позиції могло виступати й -ы: Ащерн Ханданьскы ОБ 12 зв. (2); с४АБы ТвоА БйЫ Ч 1617, 10; ЩЕАротЫ твоА многЫ Ч 1617, 18. В ОБ, крім того, -н зафіксоване не лише після задньоязикових: Черна єсмь а(з) н

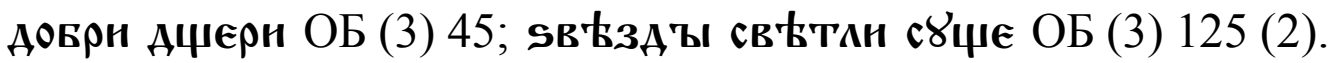

У старослов'янській мові іменні прикметники 3 основами на м'які приголосні, як і іменники колишніх ја-основ, мали закінчення -л [8, с. 125]. Таке ж закінчення для подібних утворень рекомендоване й граматикою М. Смотрицького: Име(н): ... тн ннща СмГр 156; ти сйовна СмГр 161. У розглянутому матеріалі зафіксований лише один випадок уживання в наз. мн. іменного прикметника жін. р. $з$ основою на м'який приголосний. При цьому прикметник має закінчення -а: прїйдоша песїа м४Хъ ОБ (3) 21. 
Родовий відмінок. У род. в. мн. іменні прикметники всіх родів характеризувалися, як і в старослов'янській мові [8, с. 125], а також відповідно до рекомендацій граматики М. Смотрицького, нульовими закінченнями. Такі форми в невеликій кількості виявлені лише в окремих пам'ятках (переважно в ОБ, а також у Ч 1617 та $B B$ ). Більшість із них це

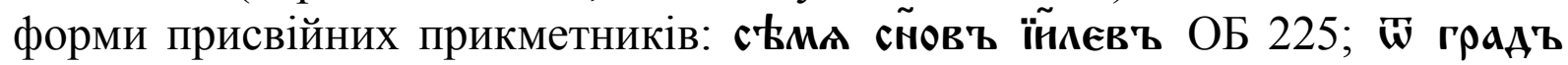

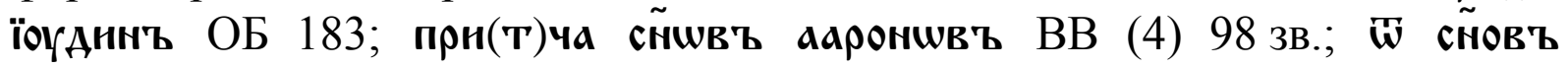

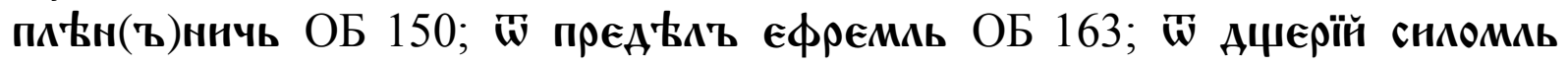
ОБ 121 (2); Хвала пьснїй Давїдшвъ Ч 1617, 99. Зрідка трапляються прикметники інших розрядів: в р४ц' м8(ж) нноязыче(н) ОБ (3) 135 ; $і$

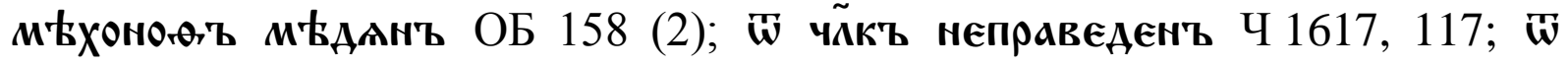

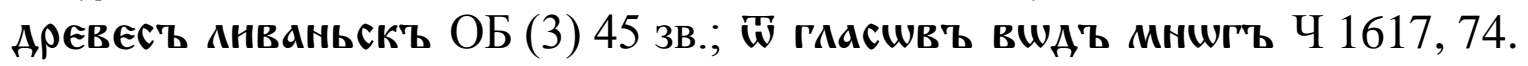

Давальний відмінок. Цей відмінок представлений також невеликою

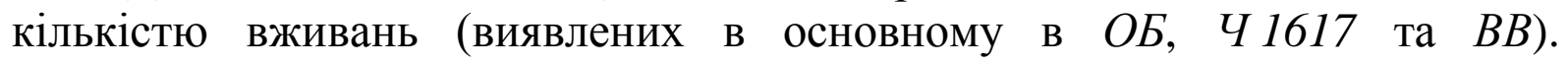
Прикметники чол. та середн. родів у дав. мн. мали закінчення -шмъ (після твердих приголосних) та -емъ (після м'яких): сіноъ гадовомъ ОБ 77 (2); сйовшмъ Іъранлевшмъ Ч 1617, 52; Конецъ (тропарям) Бгорошанчншмъ,

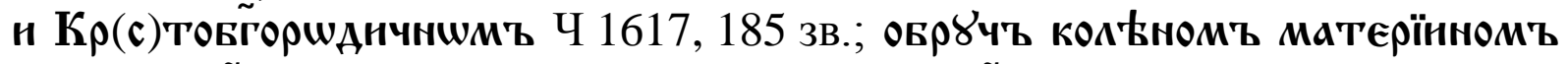
ОБ 128; спймъ венїамӥнемъ ОБ 77 (2); къ сйомъ ам(ъ)монемъ ОБ (3) 135. Для прикметників жін. p. було характерним закінчення -амъ: це̃квамъ гаматїнскамъ ВВ 95; церквамъ ьӝїамъ ВВ 7 зв.

Звертає на себе увагу те, що в граматиці М. Смотрицького форма дав. в. мн. нечленних прикметників не представлена. У парадигмах у цьому відмінку подані лише членні прикметники: Да(т): тымъ Gг̃ СмГр 148; воггнмъ СмГр 152 і ін.

Знахідний відмінок. У знах. в. мн. прикметники чол. $\mathrm{p}$. характеризувалися закінченнями -ы, -н, -л (-а). Після основ на тверді приголосні, крім задньоязикових, у переважній більшості випадків виступало -ы: в(ъ) п४тн крнвы ОБ 111 зв.; наполнихъ три немаль съсудиь ПМ 120; ВосХвалн(м) м४жа славны ПКП 21. Після задньоязикових частіше використовувалось - $\mathbf{n}$, хоча могло бути представлене й -ы. При цьому чергування $2, \kappa, x$ із з', $u^{\prime}, c^{\prime}$ перед -н не

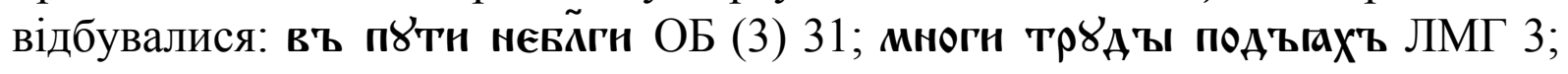
ШврацУ ... вСА веАнкН АНН ЕА ОБ (3) 159 Зв. (2); СЪХранНХЪ ПОГТТ ЖЕстоКн Ч 1617, 77 зв.; за всА ... скоТЫ АЕвнТскЫ ОБ 61 (2); Аа АасТЪ ... каменн сарданьскЫ ОБ 42; Внд Қв(ь) Же многЫ фарнсеА ВВ 46.

Прикметники 3 основами на м'які приголосні частіше мали закінчення -л (характерне для подібних форм ще у старослов'янській мові [8, с. 125], а також рекомендоване і граматикою М. Смотрицького: Ви(н): ... ТЫ ннџа СмГр 155; сйовна СмГр 160): Пожре столпЫ, арнона ОБ

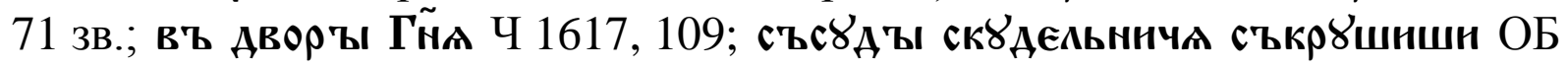


(3) 1. Зрідка (в ОБ) подібні форми могли мати закінчення -н: възда

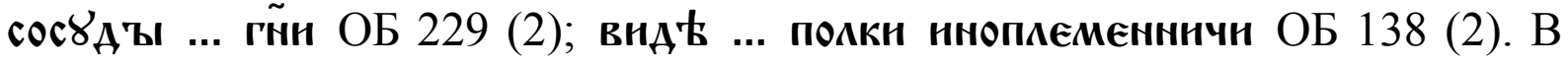
окремих випадках -н трапляється й після інших приголосних: вндАше ...

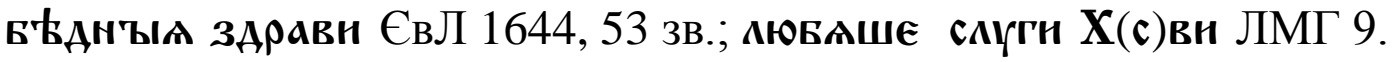

Форми знах. в. мн. іменних прикметників середн. p. у переважній більшості випадків мали, як і в старослов'янській мові, закінчення -а (після твердих приголосних) та -А (після м'яких): Аалъ есн ... повеленї̈ Бг̃га ОБ 225 (2); мншга сътворниъ есть словеса ВВ (4) 2 зв.; въ мҺста св ВтАа Ч 1617, 23 зв.; многа чудеса ... творить ПМ 112; возможн ...

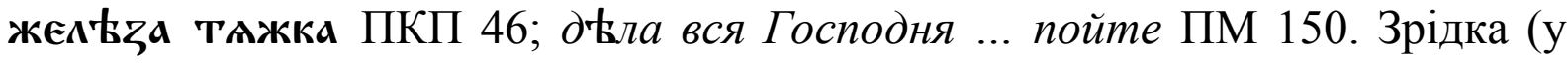
Ч 1617 та ПМ) трапляються форми знах. в. на -ы, -н: прїнм(ъ) ... нстА弓анїа неПраведнЫ Ч 1617, 22 нн; основанїА крБпкЫ положнв(ъ) Ч 1617, 12 нн; мншгн оүказанїл нмамы Ч 1617, 20 нн; разграбивиимь же намъ многи села ..., наполнихомъ ... корабль ПМ 54. Звертає на себе увагу те, що у Ч 1617 всі такого типу форми вжиті у передмові.

Іменні прикметники жін. р. в знах. в. мали закінчення -ы, -н, -х (-а). Після твердих приголосних (крім задньоязикових) частіше виступало -ы: прннеснте вһТвн маслнчнчы ОБ 225; пусты хвалы творяше ПМ 114; въ

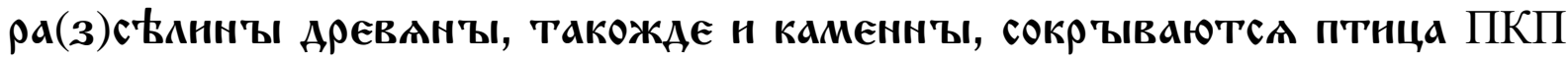
29. Після задньоязикових, як i в прикметників чол. p., частіше представлене -н, хоча зрідка вживалося й -ы: съставн вранн многн ОБ (4) 1; многи добродытели творяше ПМ 68; на горы высокн ОБ (4) 6 (2); ранъ тяжки возиожи ПКП 182; многЫ кровн пролїАһъ есн ОБ 195 (2); соврашл севе вшльzни мншгы ВВ 93. Чергування перед закінченнями в такого типу формах, як і в чол. р., зазвичай не відбуваються. Виняток становить лише одне вживання: кемїн поставнша мнози ПКП 9.

Після основ на м'які приголосні прикметники жін. р., як і чол., у більшості випадків мають закінчення -А: Аа Ааст” ... кожа овнА

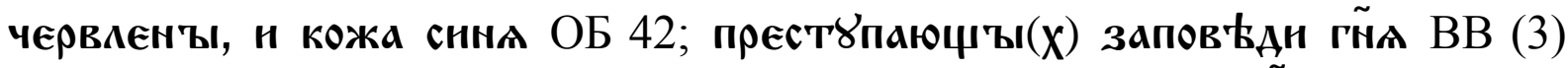
162 зв.; преступити Божіа запов ПКП 97 зв. Зрідка, в основному в ОБ, трапляються випадки вживання після м'яких Приголосних -н: на колесннцЫ амннодавАн ОБ (3) 46 (3); на Хоругввн венїамнни ОБ 128; поворан врани ги̃н ОБ 133 (2). У ПКП, крім того, зафіксована форма на -t: напастн нема' ... претерп' ПКП 11 зв.

Орудний відмінок. Цей відмінок представлений всього кількома вживаннями прикметників чол. та жін. родів (виявленими в $O Б, ~ B B$ та ПМ). Форми чол. р. в ор. в. мають закінчення -ы або -н: на(А) сїъ ӥйлевы ОБ 185 (2); съ цроп иїмевъ ОБ 178 (2); съ многи клеврьты ПМ 49. Для жін. р. були характерним закінчення -амн, -лмн: странамн многамн ОБ 87 (2); печал(ь)мн ЖнТїнскамн ВВ 118 зВ.; КУПААмн ЖнТїнскамн ВВ 141; Аа сътворншн покровъ Храм४, кожамн овнАмн ОБ 37 (2). У граматиці 
М. Смотрицького такі форми відсутні. У парадигмах в ор. в. подані лише

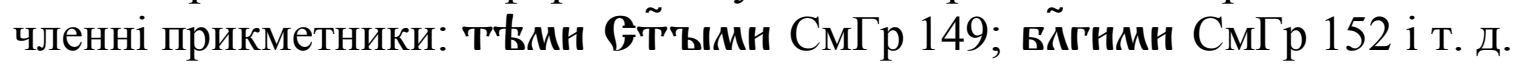

Місцевий відмінок. Форми місц. в. мн. нечленних прикметників у розглянутому матеріалі $\epsilon$ також загалом рідкісними, представлені поодинокими вживаннями.

У старослов'янській мові іменні прикметники чол. та середн. родів у місц. мн. мали закінчення - $\mathbf{k} \mathbf{3}$ (після основ на тверді приголосні) та -нхъ (після основ на м'які) [8, с. 125]. У результаті стягнення займенникових закінчень форми місц. мн. членних і нечленних прикметників з основами на м'які приголосні збіглися (обидві характеризувалися закінченням -нХ'ъ). У церковнослов'янських текстах кінця XVI - XVII ст. всі подібні утворення, очевидно, слід вважати повними. Серед розглянутого матеріалу iз прикметників чол. і середн. родів у місц. мн. формальну ознаку приналежності до нечленних (закінчення -\$Х⿸厃) мають усього кілька

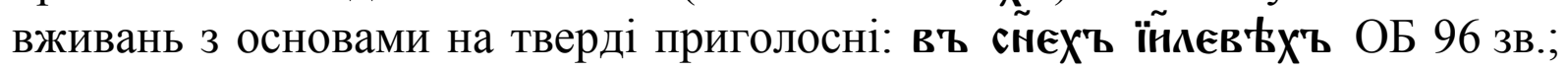
по АнеХъ мнш弓'Хъ ПКП 47 зв.; По мнш弓'Х(ъ) же тр४деХъ ПКП 171;

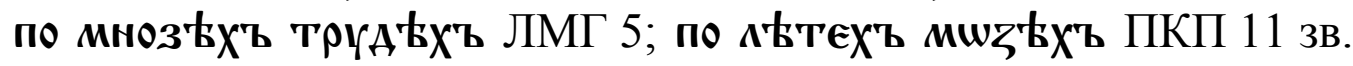

Прикметники жін. р. у цьому відмінку характеризуються

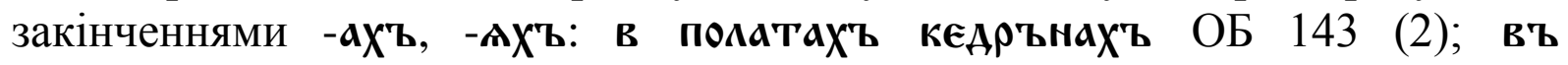

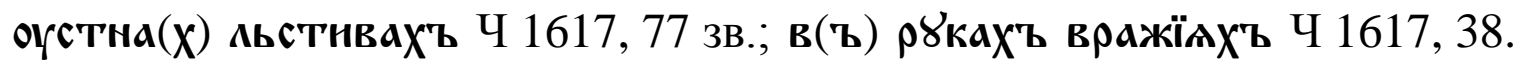

У граматиці М. Смотрицького форми місц. мн. нечленних прикметників відсутні. В парадигмах подані лише займенникові: Gка(з): w

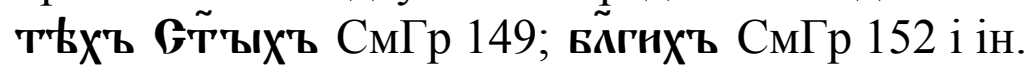

Кличний відмінок. У кл. в. мн. іменні прикметники виступали із тими ж закінченнями, що й у наз.: ва(с)внте Га̃ в(ъ)сн равн Гйн Ч 1617, 22 зв.; ршженїа ехїднова, кто сказа вамъ ВВ 46; АщерА їер(с)пӥмовы не пМачнтеСА BВ 116 зв.

\section{Двоїна}

У двоїні іменні прикметники представлені невеликою кількістю вживань. Більшу частину їх становлять форми наз. та знах. відмінків. Прикметники чол. р. у цих відмінках характеризувалися закінченням -а: Овенъ ... ТОМУ же Ава рога, рога ЖЕ вЫсока ОБ (3) 155 (2); оБа БАГч(c)тнва сУща ПКП 90; БЊста АВа м४жа славна ПКП 117; сътворн

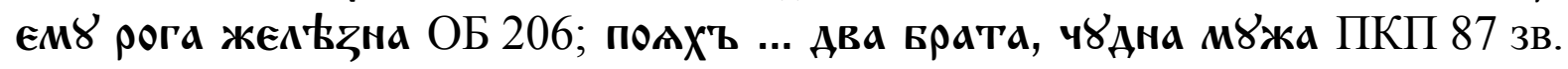

Форми наз. і знах. відмінків жін. та середн. родів мали закінчення -t (після твердих приголосних) та -н (після м'яких): дв к крыль гол४вннь

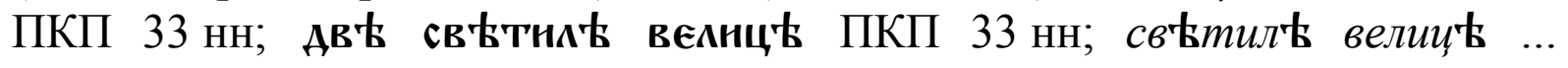

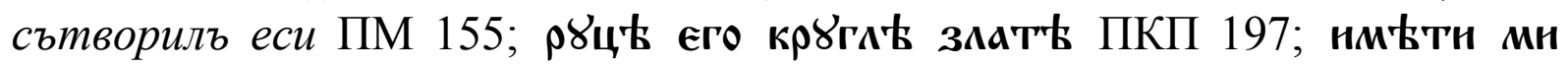
своводн' рУц' ПКП 197; ав' крыль орАн ПКП 33 н; полт(ъ) ... Ав' сестр' НАрославли ПКП 179.

Такі ж закінчення в наз. та знах. дв. мали прикметники у старослов'янській мові $[8,125]$. При цьому вони не зовсім відповідають 
рекомендаціям граматики М. Смотрицького, у якій у парадигмах для чол. та середн. родів подані однакові закінчення: Име(м): Вн(м): н Зва(т): та

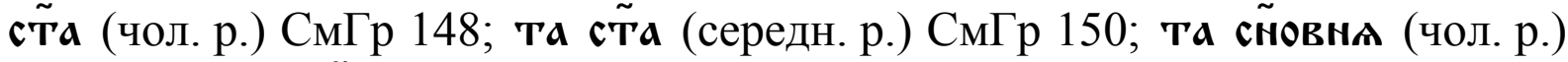
СмГр 160; та сйовна (середн. р.) СмГр 162.

Крім того, у розглянутому матеріалі зафіксовано кілька форм род. та місц. відмінків дв. Вони мають закінчення -8, -ю (які вживались у старослов'янській мові, а також рекомендовані граматикою М. Смотрицького): Пронзводат(ъ)Са ... нашъ /вашъ, $\mathbf{G}$ роднтекнУ

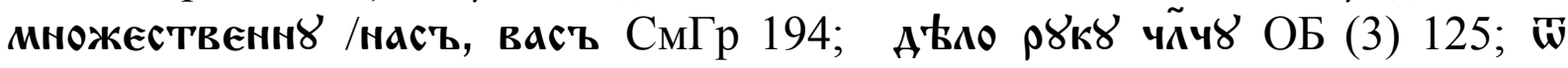
р४кУ ИродовУ ПКП 267 зв.; Оувьченъе

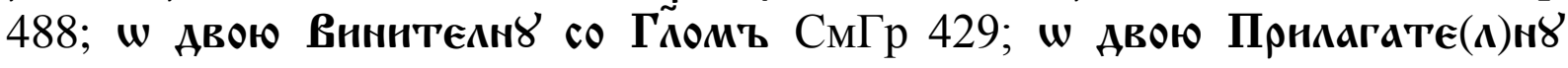
СмГр 392; ХОАан на крниУ в

Отже, проаналізований матеріал дозволяє зробити такі висновки.

1. Іменні прикметники в церковнослов'янській мові української редакції кінця XVI - XVII ст. були достатньо вживаними й виступали як у предикативній, так і в атрибутивній функціях. Разом із тим, нерівномірна представленість форм наз. в., з однієї сторони, і форм непрямих відмінків, 3 іншої, свідчить про початок поступового виходу 3 ужитку іменних прикметників в атрибутивній функції, що створювало умови для руйнування їхньої відмінкової парадигми. Підтвердженням того, що такий процес розпочався, є також граматика М. Смотрицького, у якій рідкісні в обстежених пам'ятках форми не подані, очевидно, через їхню, на думку автора, неперспективність Однією з причин зазначених змін був уплив тогочасної української мови, у якій форми непрямих відмінків іменних прикметників уже були фактично відсутні.

2. Розглянуті іменні прикметники, на відміну від української мови, переважно зберегли окремі закінчення для різних родів у множині. Однак, варіанти форм наз. та знах. відмінків (хоч і нечисленні) свідчать, очевидно, про початок уніфікації системи множинних закінчень. Відбувалося це, зокрема, і в результаті впливу української мови.

Перелік умовних скорочень назв використаних джерел

ВВ - Василій Великий Книга о постничестві. - Острог, 1594 (друкарня Костянтина Острозького). - [7], 160, 292, 143, [1] арк. (стародрук).

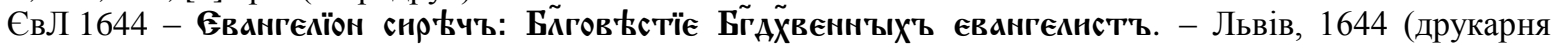
братства). - [12], 412 арк. (стародрук).

ЗизГр - Зизаній Л. Граматіка словенска. - Вільно, 1596. - 180 с. (Факс. перевид. К.: Наукова думка, 1980, підгот. В.В. Німчука).

Лим - Лїмонаръ. GнрҺчъ, цв тннкъ. - Київ, 1628 (друкарня Соболя). - 183 арк. (стародрук).

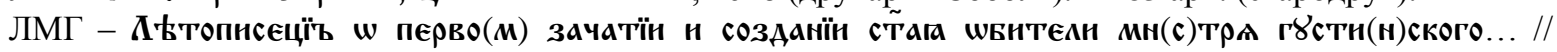

Чтенія въ императорскомъ обществе исторіи и древностей россійскихъ. - М., 1848. - № 8. - С. 1 - 46.

ОБ - Бнвлїа снрьч кннгы ветХаго и новаго зав Тта. - Острог, 1581. - 628 арк. (стародрук).

ПКП - Патерїкъ нкн штечннкъ пєчерскїй. - Київ, 1661 (друкарня лаври). - 314 арк. (стародрук).

ПМ - Собственноручныя записки Петра Могилы // Архивъ Юго-Западной России, издаваемый коммиссіею для разбора древнихъ актовъ. - Часть I, томъ VII. - Кіевъ, 1887. - С. 49 - 180.

Син - Синопсіс // Українська література XVII ст. - К.: Наукова думка, 1987. - С. 167 - 181.

СмГр - Смотрицький М. Грамматїкн славенскїл правнаноє Яунтагма ... - Єв’ 1619 (тип.

Віленського братства). - 492 с. (Факс. перевид. К.: Наукова думка, 1979, підгот. В.В. Німчука).

Ч 1617 - Часослов. - Київ, 1617 (друкарня лаври). - [21], 190, [2]. 


\section{Література}

1. Вайан А. Руководство по старославянскому языку / А. Вайан. - М. : Издательство иностр. литературы, 1952. - 446 с.

2. Грищенко А.П. Прикметник в українській мові / А. П. Грищенко - К. : Наукова думка, 1978, 207 с.

3. Керницький I. М. Система словозміни в українській мові. На матеріалі пам'яток XVI ст. / I. М. Керницький - К. : Наукова думка, 1967. - 288 с.

4. Мова беларуской пісменнасці XIV - XVIII стст. / А. М. Булыка, А. I. Журауски, I. I. Крамко, У. М. Свяжынскі. - Мінск : Навука і тэхніка, 1988. - 319 с.

5. Німчук В. В. Староукраїнська лексикографія в іiї зв’язках з російською та білоруською / В. В. Німчук - К. : Наукова думка, 1980. - 304 с.

6. Німчук В. В. Мовознавство на Україні в XIV - XVII ст. / В. В. Німчук - К. : Наукова думка, 1985. - 223 с.

7. Русанівський В. М. Джерела розвитку східнослов'янських літературних мов / В. М. Русанівський К. : Наукова думка, 1985. - 231 с.

8. Селищев А. М. Старославянский язык / А. М. Селищев. - М. : Гос. учебно-пед. изд-во Мин-ва просв. РСФСР, 1952. - Ч. ІІ. - 206 с.

9. Толстой Н. И. Значение полных и кратких форм прилагательных в старославянском языке / Н. И. Толстой // Вопросы славянского языкознания - М. : АН СССР, 1957. - Вып. 2. - С. 43 - 122.

10. Толстой Н. И. История и структура славянских литературных языков / Н. И. Толстой - М. : Наука, 1988. - 239 с.

11. Хабургаев Г. А. Очерки исторической морфологи русского языка. Имена / Г. А. Хабургаев. - М. : МГУ, 1990. - 296 с.

12. Шахматов А.А. Историческая морфология русского языка / А. А. Шахматов - М. : Гос. учебно-пед. изд-во Мин-ва просв. РСФСР, 1957. - 400 с. 